\title{
Reception Analysis of Related Audience by Watching "Sexy Killers" the Documentary Film
}

\author{
Dionni Ditya Perdana ${ }^{1}$ \\ ${ }^{1}$ Department of Communication Studies/ \\ Faculty of Social and Political Science, University of Bengkulu, Indonesia \\ Coressponding Author's Email : ddperdana@unib.ac.id
}

\begin{abstract}
Sexy Killers" is a documentary film whose occurrence steal public attention and caused much controversy. "Sexy Killers" tells the story of coal mining is still a compelling business in Indonesia despite endangering environmental conditions. The Film also displays the number of state officials involved in coal mining, some of which surprised the audience. Uploaded by "Watchdoc Image" Youtube channel on April 13, 2019 only intermittent four days before the elections, "Sexy Killers" successfully pulled about 27 million views. That documentary film become a public discourse, especially related to the group of entrepreneur and government employee who's a lot of contact with the sector. So this research interesting to study and analyze how messages are captured on the film's audience. From the research, we concluded that the documentary film "Sexy Killers" offers meaning dominant or preferred reading is about the irony of a conflict of interest between the government and bussinesman that have an impact on people's lives About a coal mine or coal plant. The varian of meaning that found: (1) There is no oppositional reading, (2) One of the informants perform interpretation with such meaning dominant offered media texts (dominant reading), (3) Most of the informants was negotiated reading, the reading of the meaning of meaning dominant approach but include criticism or a different outlook on certain parts of the documentary film.
\end{abstract}

Keywords: documentary film, coal mines, Reception Analysis

\section{INTRODUCTION}

The emergence of the documentary film "Sexy Killers" on 13 April 2019 managed to steal the attention of the audience. The documentary produced by photo journalist Dandy Dwi Laksono and Ucok Sparta tells the story of coal mining in Indonesia. "Sexy Killers" uploaded via youtube channel "Watchdoc" and spread through social media to some circles do watch together. Sasono (2019) calls during 5-13 April 2019 occurred watch together at least in 476 locations. When uploaded on April 13, 2019 in 36 hours gets 1.5 million views. You could say there was never a movie that reached the level of success like this before in Indonesia.

Views of the documentary film "Sexy Killers" in October 2019 totaled to 27 million. The amount of public attention to this documentary raises a variety of 
discourse in society. Documentary that lifts the mine problem also alluded to the involvement of government officials, businessmen and some politicians who were active in the presidential election campaign 2019. In the documentary to show things that have not shown as explicit by conventional media. Damage to the environment and interests of companies such as irony that director want to display in the film.

It draws from the film "Sexy Killers" is mentioned Sasono (2019) that the screening is done completely independently and non-commercial as well as in spaces not intended for film shows, or non-theatrical screening, The entire screening followed by a discussion on the substance of the film, the coal industry, alternative energy, environmental issues, the oligarchs in politics, and so on. "Sexy Killers," which was released just four days before the elections, to show the relationship of both camps winning presidential candidate. The documentary film may not always be said to successfully influence public political views, but at least the subject of conversation all walks of life.

Currently it is difficult, to separate the political, cultural and commercial elements of filmmaking, (Kerrigan, 2010: 176). Separating commercial and political interests (in the broad sense) in film making is a necessity. Readings against the background of a documentary film "Sexy Killers," which is a series of 'Ekspedisi Indonesia Biru' is showing how environmental damage and the impact of coal mining and the settlement of the issue of government involvement.

The documentary, as written by Michael Chanan (2007), spoke to the audience as individuals in their political and social situation. Thus, the opportunity to form a narrative documentary that takes viewers public role as citizens-or-greater than fiction films that exploit and manipulate the psychological condition of the audience, (Sasono, 2019). The strength of a documentary film featuring the 'actors' and 'background' real easily be ignited an emotional audience. Moreover, if the film is directly related to political views, ideology, culture and interests of the audience.

Film of course charged a message that will be conveyed to the audience. But the message that captured audiences over medium text presented can vary and depend on the cultural background of the audience. That perspective view an active audiences in interpreting the message. So it becomes interesting to analyze the meaning of the dominant offered (preferred reading) and variations of meaning that appear on a documentary film "Sexy Killers". With Reception Analysis will answer how the message produced by the media can be interpreted by the audience.

\section{LITERATURE REVIEW OR RESEARCH BACKGROUND}

\section{Films: what stands behind}

while watching slides projected quickly and sequentially, they see these pictures as if they were moving, (Baran, 2012: 212). That is a preliminary picture of what is called a movie. Of course the film is now much different from 1877 where Myubridge featuring slides of horse racing. Although some people still 
perceive the film as an entertainment, basically the same as with other mass media, the film carries the message of the text presented.

firstly, the film can be used as a social marketing tool, inspiring attitude or behavior change, and at the least, Increased awareness. Secondly, film plays a significant social role Embracing political, artistic and commercial spheres. As filmmaking Grew more sophisticated, the social and political roles Became evident and films were used in order to instill political ideologies or to express artistic vision, (Kerrigan, 2010: 177). Generally documentary stand behind the ideology, the making time-consuming and cost is certainly not possible without purpose. Although the purpose of the message of the film maker is not necessarily the same as what was captured audience.

Wohlfeil and Whelan (2006) Correctly note that our understanding of motivation for movie consumption may lie in the methods the which have been used to understand such consumption. They call for a turn towards more interpretive methods in order to understand consumption of movies and illustrate the value of Subjective personal introspection as an insight into this consumption, (Kerrigan, 2010: 106). The reason for taking a movie very Subjective start spending spare time to search for a new perspective.

technological change brought disruption in the way of watching films that previously required to go to the cinema with a busy audience. Because this time watching movies can be via a personal device. Live streaming or youtube, legal or illegal, flooding the online media. In addition chirp strength in social media, can predispose a person to consume a movie. We will not go too deep on the packaging of a film, said little about how the concept of a film built.

movie concept is a film that can be described in one sentence, (Baran, 2012: 239). What is the "Sexy Killers" include the use of film concepts?. Although beberana scene talking about death (humans, plants, coral reefs, fish) but the film is not really appoint killers intended. "Sexy Killers" invites the audience the audience to actively participate in the interpretation of what or who the killer was intended, and why it is called 'sexy'.

\section{Meaning Construction by Active Audience: Reader-Response Theory and Reception Analysis}

Some view call if the audience is the consumer or recipient of the message. But not with the reader-response theory and reception analysis, they looked at the audience are producers of meaning. Stanley Fish in Littlejohn (2009: 196) mentions that the meaning lies in the reader. Readers is a member of the interpretative community - a group of interacting, shape reality and common meaning.

As a culturists approach, meaning negotiated individuals based on their life experiences. Audiences with different cultural backgrounds, ideologies, and their stock of knowledge will differ in interpreting a text message from the media. Reception Analysis (Hadi, 2008: 2) has an argument that contextual factors influence the way you watch or read media audiences, such as a movie or television program. So often we met impressions (film) labeled specific categories 
of target audience, it could be linked so that messages can be received by the appropriate audience.

Fish said that the reader is always projecting purposing them into features a script and just come up with their own meaning in the end, (Littlejohn, 2009: 197). Reception analysis perspective view messages delivered when the media will be the meaning of a process of reception of the audience. As mentioned McQuail (1997) that the reception analysis emphasizes the use of media as a reflection of the socio-cultural context and as the process of giving meaning through public perception and experience of production, (Hadi, 2008: 5).

Variations of meaning may arise from different interpretations of the audience of the message. Three main types of interpretation or reading of the text media audience:

a. The dominant-hegemonic; when audiences do signification within the meaning of the dominant (preferred reading) offered by the media text.

b. The negotiated reading; when the audience recognizes the legitimacy of the dominant code, but adapting the corresponding readings of their social condition.

c. The oppositional reading, occurs when a radical reading of the text or the opposite with preferred reading.

But before comparing with the response of readers to the meaning of the message, reception analysis, first find the dominant meaning posed by the media (preferred reading). Borrowing a semiotic analysis to expose the hidden meaning behind the sign in the text media. In semiotics, according to Barthes (2010: 20) There are three types of messages are:

1. Linguistic messages signed with captions and labels

2. Message iconic objects are identified and commonly seen in everyday life.

3 . Is the literal message that is tautological relationship between the signifiersignified. by required knowledge related to our perception.

The meaning of a sign in the film obtained through the analysis denotativeconnotative text shown on the media. Spot also has a coating that is:

1. Informational layer is anything that can be absorbed from the background (setting), the costumes, the layout, character, contacts / relationships that occur in anatara offender.

2. a symbolic layer

a. referential symbolism

b. symbolism diegesis

c. symbolism einsensteinian

d. historical symbolism, (Barthes, 2010: 40). 


\section{METHODOLOGY}

This research is the study descriptions using a qualitative approach. Kriyantono (2010: 69) states that the type of descriptive research aims to make a systematic description, factual and accurate about the facts and the properties of the population or a particular object. As for the facts to be obtained with regard to the meaning of a message from the public related to the documentary film "Sexy Killers".

The methodology in this study using Reception Analysis. In the methodology, reception analysis included in the paradigm of interpretive constructivist, where Neuman (2000: 71) approaches interpretive "is the systematic analysis of socially meaningful action through the direct detailed observation of people in natural settings in order to arrive at understandings and Interpretations of how people create and maintain Reviews their worlds "(Hadi, 2008: 4). Reception Analysis included in the culturalist approach, in which meaning by media is negotiated based audience background. But even so, the audience interpreted as a member of the interpretative community.

Reception analysis refers to a comparison between a textual analysis of media discourse and public discourse, which results interpretation refers to the context, such as the cultural setting and context for the content of other media (Jensen, 2003: 139), (Hadi, 2008: 5). Due to the wilderness as active audiences constructing meaning of the message delivered media, the possibility of variations in meaning very big chance. This study must first do a reading about the meaning that is predominantly offered in text (preferred reading).

To find the meaning of the dominant or preferred reading it is necessary to analysis to answer the meaning behind the sign / text displayed media, so the semiotic analysis needs to be done. Danesi (2010: 14) in his book "Messages, Signs, and Meaning" Roland Barthes mentions that illustrates the power of using semiotics to dismantle the structure of the hidden meaning in the spectacle, the show daily and general concepts.

Through images and text shown in the documentary film "Sexy Killers" researchers sought to discover the meaning of the dominant emerging. Barthes (2010: 3) mentions that the reproduction of the reality of the image, painting, cinema and theater formed analogously. Messages analogical build a supplementary message (sort of analogical uterine lining itself). In other words, all the arts 'imitative' contains two messages: (1) denotation, and (2) connotative (the public's view of what is offered to him).

The next stage of this Analysis Reception after finding the preferred reading of the documentary film "Sexy Killers" is interviewing audiences to determine variations in the meaning that appears. This study focuses on the meaning of the message carried by the related group. So that the interview was conducted to the informant who meet the following criteria which work in government or an entrepreneurs. 


\section{RESULTS AND DISCUSSION}

Preferred Reading: an irony between the conflicting interests of the government and mining entrepreneurs that expense of citizenry

To find the meaning of the dominant offered in the film "Sexy Killers", researchers will analyze the denotation and connotation are displayed. As Barthes (2010: 12) mentions that the text is a parasite message designed to connote images / 'coat' image with the second marker. Therefore, researchers classify some signs which often recur in the scene-scene documentary film "Sexy Killers".

a. Taking pictures of altitude to catch on a broad overview of the area.

One of the most frequently appeared in the documentary film "Sexy Killers" is a shooting technique using drones to display a picture of the mining area adjacent to the farm / field, plantation, and neighborhoods. Similar techniques are also used to display the coal barges that cross from Borneo island to Java island whose existence is not far from the area where fishermen catch fish. In addition, to demonstrate the impact of environmental degradation, such as former excavation pit mines.

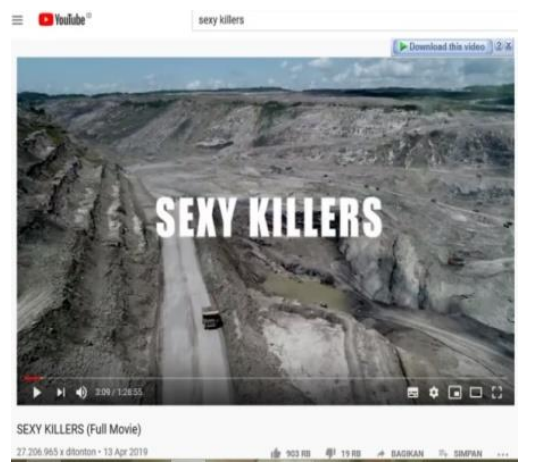

Pic. 1a

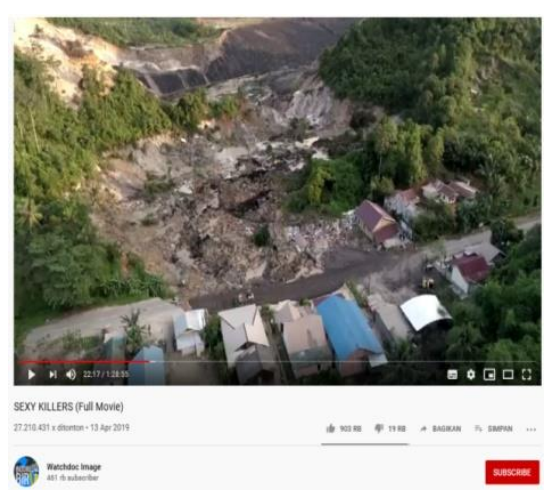

Pic. 3a

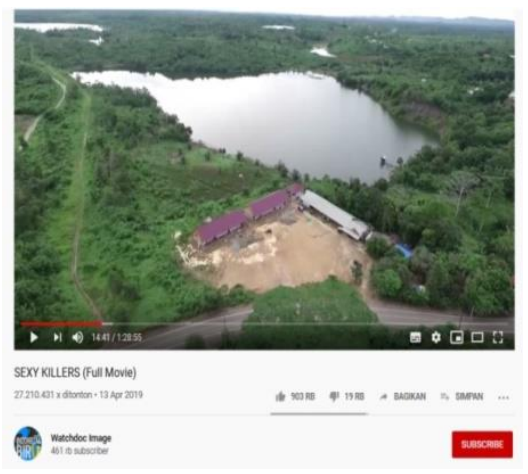

Pic. 2a

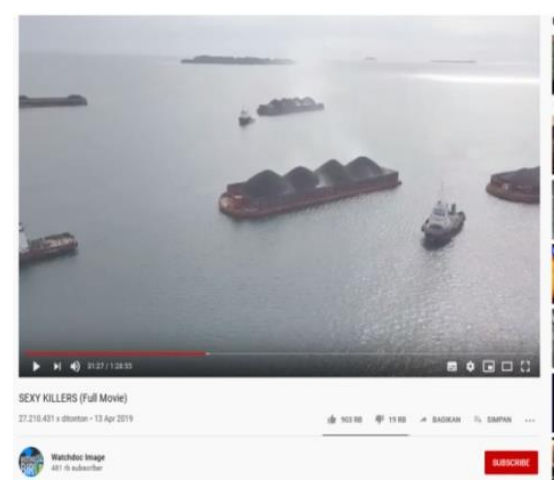

Pic. $4 \mathrm{a}$ 
A big hole like a lake that is the former mine pits that are not adjacent to school revitalization (pic.2a). The scene in the film, is used to support the story of many children who sink in it. The next picture shows the settlements adjacent to the mine area (pic 3a). The scene tells the story of mining impact on shifting ground, the collapse of the road, and many houses were cracked. Coal barge traffic in Karimun (pic 4a) in question fishermen because it makes the area for fishing to be limited, in addition to the pollution of coal reduces the quality and quantity of the catch.

In connotation, mining areas allowed by the government did not notice anything but the interests of the coal business itself. Comfort children playing in the open green space, comfort people to live and work (fishermen, farmers) did not receive special attention.

b. The emphasis on the peculiarities of a documentary film, "Sexy Killers" featuring excerpts of interviews conducted spontaneously by the people.

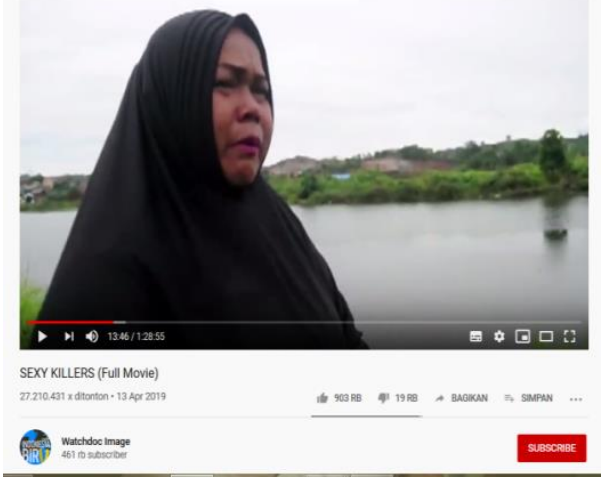

Pic. $1 b$

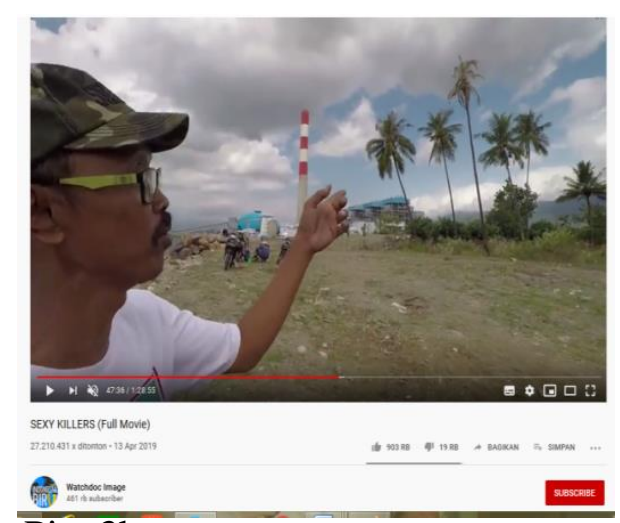

Pic. 3b

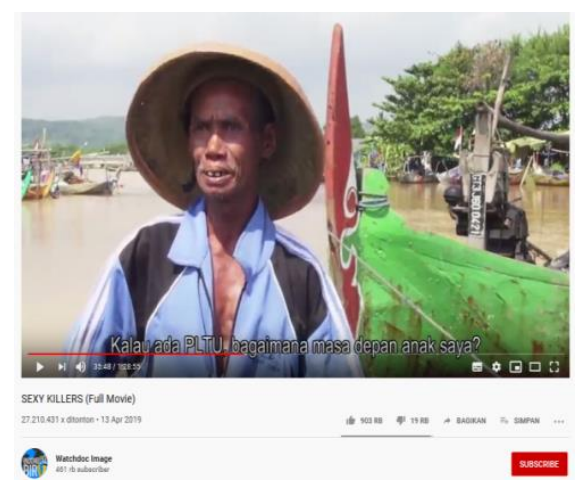

Pic. $2 b$

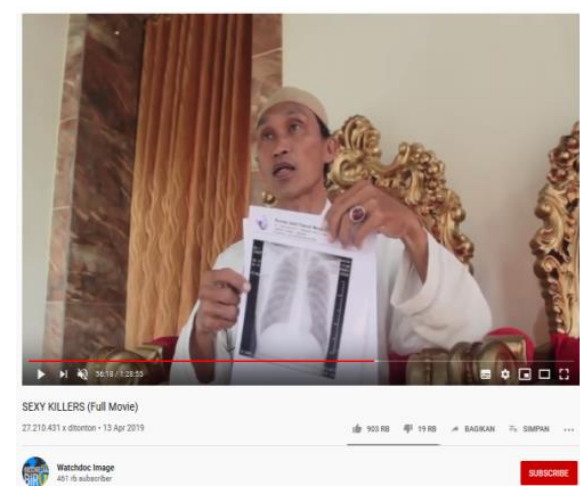

Pic. $4 b$

From the number of the interviews in the documentary film "Sexy Killers" These four squat about the screenshot image narration public disappointment over the government. 
A mother who lost her child to drown in an excavated pit mine and no responsibility of government (Pic 1b). A fisherman with anxiety about the future families who depend on the sea while coal waste began to pollute (pic 2b). A farmer who does not want to give up the land but had to decline the quality and quantity of his crop due immediately next to the power plant (pic 3b). A citizen who resides adjacent to the coal mining area shows the results of X-ray of the lungs (pic 4b).

The interview excerpts repeatedly stressed in public about the plight of people who interact directly with coal mines and power plants. No special attention from the government to them.

c. Citation selection statement raises several prominent conflicts in the story line that is used to ignite a sense of emotional public audience.

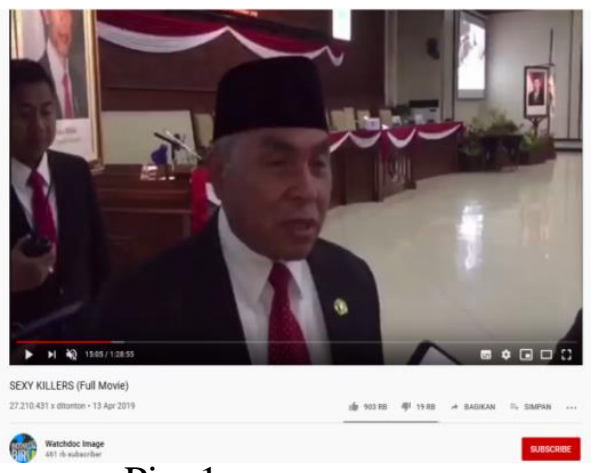

Pic. 1c

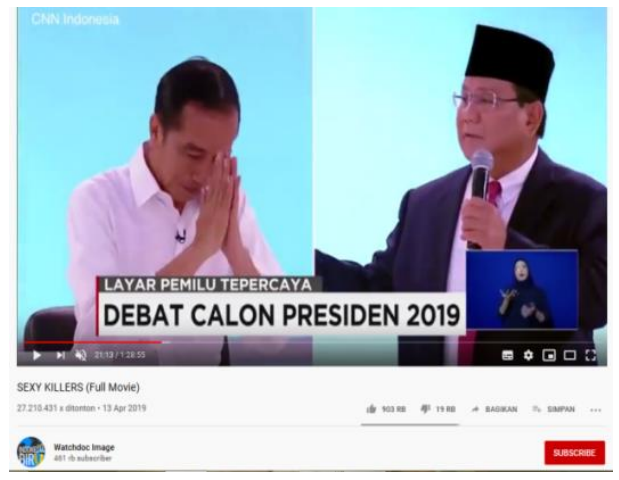

Pic. 3c
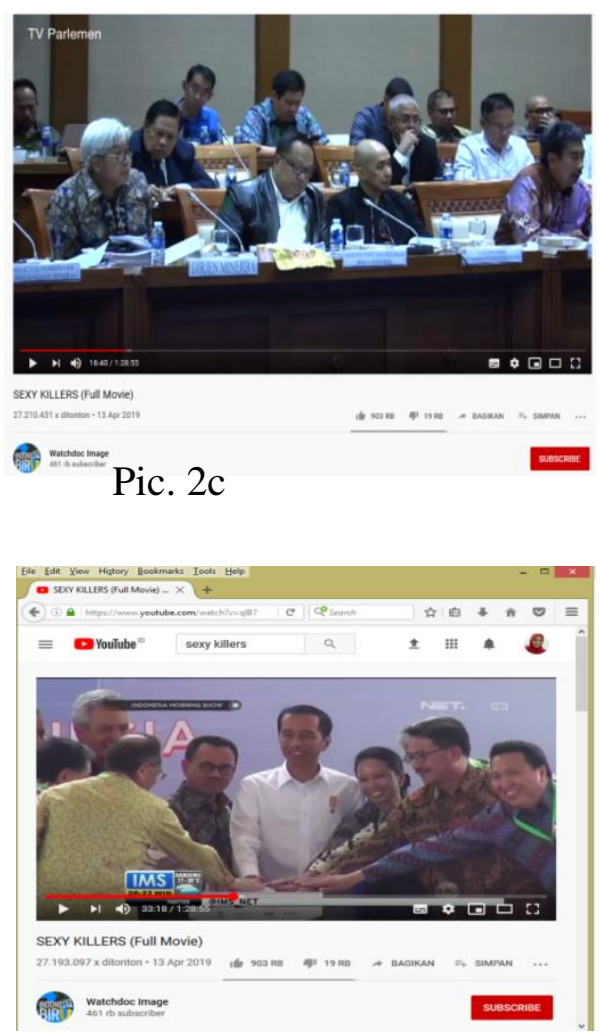

Pic. $4 \mathrm{c}$

Scene where the regent of East Kalimantan responding to a reporter's question related fatalities in an excavated pit mines. The regent statement precisely because there memiiki cornering community awareness (pic 1c). Audiences are increasingly made furious audience by including jokes at minute 15:57 "lest there is a ghost" accompanied by laughter of those around. Very sad because people can not expect the government in this regard. 
"Sexy Killers" at minute 16:41 displays 7 Parliament committee meeting with the ministry of Energy and the coal mine owner (Pic 2c). Footage meeting in the film led to indecision answers about the revitalization of the former mining area.

Audience emotionally more stirring when at minute 19:02 Jokowi appear ovation followed by Prabowo, where there was footage course of presidential debates in 2019 (pic 3c). Mine issue is not taken seriously and no meaningful debate. The snippets of dialogue that occurs as follows:

Prabowo: "I think it is quite yes to this problem, for what rambling again"

Jokowi with the spirit repeatedly nodded and smiled.

Prabowo "if it is not too much difference to what we fuss again, sir?"

Jokowi laugh by showing her teeth. seemed happy.

Jokowi: "I agree is the only".

This has become one of the media message that there is no hope for change in the next governance in dealing with the problems of society as a result of the coal mine and power plant.

d. Chart description proprietary data mining company, to be effective to give explanation to the audience

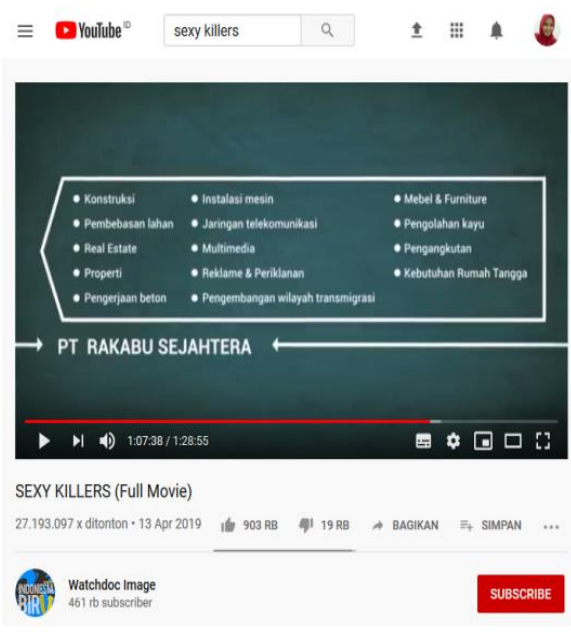

Pic. 1d

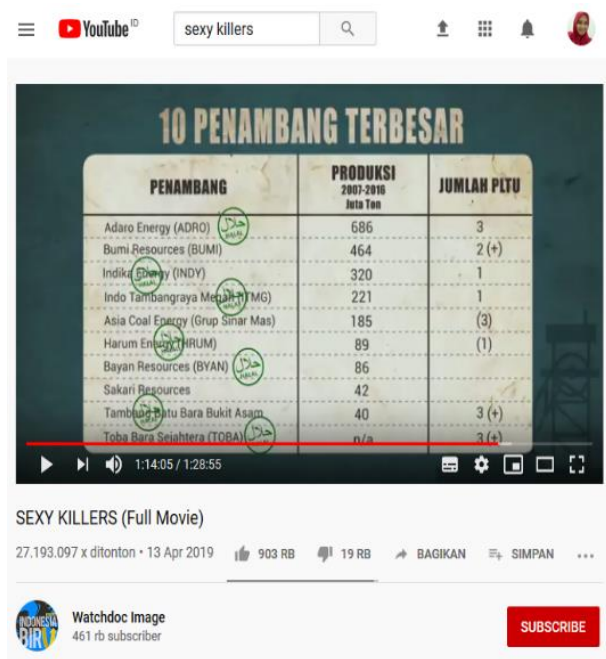

Pic. $2 d$ 


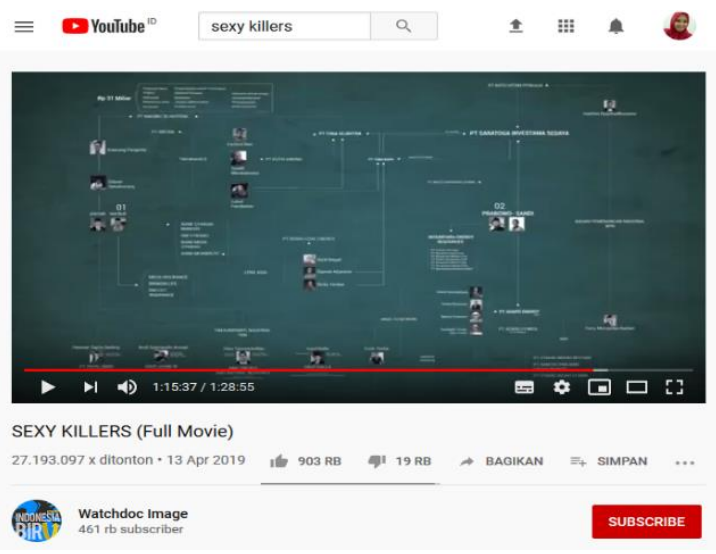

Pic. $3 d$

Chronology of ownership of mining companies in Indonesia open mind about of interests among public officials who currently also active as a 2019 presidential candidate campaign team of political oligarchy displayed explicit up may bring the audience apathy.

\section{Making of a message of a documentary film "Sexy Killers" by the relevant audience}

After discovering the meaning of the dominant offered the audience is about the conflict of interest between government officials and involvement in mining in Indonesia. Reception Analysis followed by interviewing related audiences that selected in this study that an entrepreneurs and government officials.

The whole informant obtain information on their documentary film "Sexy Killers" through social media so as to make them interested to watch it on youtube channel "Watchdoc". Our results are for the three variations of meaning:

1. Dominant reading: Occurs when a person or group of people doing signification within the meaning of the dominant (preferred reading) offered by the media text.

one of our informants, who works as an ASN, said that the documentary film "Sexy Killers" made aware of the impact of the mine, regulation and government elite alignments. Three things are become new knowledge for him.

"Documentary film" Sexy Killers "is not intended to provide awareness about energy saving but to show partiality regulator against the mining industry." quote the informant statement we categorize that this informant conduct within the meaning of the dominant interpretation offered by the media.

"The issue of mine needs to be addressed by using alternative power sources." Quote informants statement also points to the approval of the losses borne by the public and environmental damage to ecosystems due to coal mining or coal plant is causing problems for farmers and 
fishermen. The second message is always shown repeatedly throughout the film.

2. Negotiated reading: Occurs when informants recognized the legitimacy of the dominant code, but adapting the corresponding readings of their social condition.

Most informants we interviewed in this group. The answer given by the informant led to the dominant meaning that arise but with another point of view to the film or to the question of coal mines in Indonesia.

Here's an excerpt of one informant who set employment as employers "available documentary film" Sexy Killers "I think trying to raise awareness about mining in Indonesia but is not showing the balance." This statement shows an agreement on the one hand the dominant meaning featured in the film. However, informants do not fully agree to the message by calling it unbalanced.

Another informant opinion that entrepreneurs also mentions that "The issue of mining in Indonesia, which must be addressed is to tighten the EIA." The statement of the informant actually leads to the truth about the impact of coal mines and power plants that harm the community. But the expected direction of the preferred reading is to replace coal with other renewable energy, while the informant saw the problem is on the EIA.

"The film" Sexy Killers "provide new knowledge about foreign entrepreneurs who set all the policies in Indonesia." The idea of informants who are government employees can be said to be out of the box. The dominant meaning is talking about the government and business conflicts of interest but not raised explicitly linkage other nations. "All political interests. This film does not touch the real entrepreneurs who our mineral natural resources. This film does not peel strength of the actual owners of foreign capital. Political figures who played in coal mines is just a puppet of foreigners. "

3. Oppositional reading: A radical reading of the text or the opposite with preferred reading.

From informants that investigators interviewed, does not appear contrary to the meaning of the dominant interpretation. In other words documentary film "Sexy Killers" was quite successful in conveying the message through the power of election signs (text or images) that are displayed.

In an extensive study of Spanish consumers during 1998, Lo'pez-Sintas and Garci'aA'lvarez (2006) Consumers audiovisual classified into five categories: (1) occasional movie-goers, (2) light movie-goers, (3) movie fans, (4) audiovisual fans, and (5) television addicts, (Kerrigan, 2010: 106). Thoroughly informant is not included in the category 'movie fans' threat in social media makes them an 
occasional movie-goers. Therefore, we do not call them as expertise needed in the field of cinema, but only because it is pulled by the growing public discourse.

The documentary film as a work of journalism is certainly not built on personal sentiment. As Sudibyo (2014: 52) mentions that the work of journalism must depersonalization (precipitate personal sentiment, personal interests, personal ties to a party or a case). Documentary film "Sexy Killers" are included in the series 'Expedition Indonesia Blue' is not built for personal gain. This is evident from the number of hope behind the 'actor' who he complains have been voiced.

George Wang (1980) mention the involvement of a conflict is a necessity journalism, (Sudibyo, 2014: 95). Then the position counter or pro ditujukkan in the documentary film "Sexy Killers" is a journalistic justification that also stand behind ideology.

\section{CONCLUSION}

From the research, we concluded that the documentary film "Sexy Killers" offers meaning dominant or preferred reading is about the irony of a conflict of interest between the government and bussinesman that have an impact on people's lives About a coal mine or coal plant. The dominant meaning is supported on the scene-scene featuring environmental damage, portrait on public complaints, and oligarchs.

Reception analysis conducted to the informant with background jobs as enterpreneurs and government officials, found that: (1) There is no oppositional reading, (2) One of the informants who are ASN perform interpretation with such meaning dominant offered media texts (dominant reading ), (3) Most of the informants was negotiated reading, the reading of the meaning of meaning dominant approach but include criticism or a different outlook on certain parts of the documentary film. For example, on the balance shown in the documentary film. The other thing is about to add interest to infiltrate foreign businessmen in the business of coal mine and power plant.

This excellent documentary film presenting the information amid the disruption information. Technological developments greatly facilitate independent films by utilizing live streaming or youtube channel. Recommended further research is the impact of social, economic, and culture by watching a movie.

\section{BIODATA}

Dionni Ditya Perdana, S.I.Kom., M.I.Kom is a lecturer of Communication Studies Dept on University of Bengkulu, Bengkulu, Indonesia. She has a research interest in media and gender studies.

Dr. Lisa Adhrianti, M.Si is a lecturer of Communication Studies Dept on University of Bengkulu, Bengkulu, Indonesia. She has a research interest in Communication Strategic. 


\section{REFERENCES}

\section{Books}

Baran, Stanley J. (2012). Pengantar Komunikasi Massa. Terj. S. Rouli Manalu. Jakarta: Erlangga.

Barthes, Roland. (2010). Imaji/ Musik/ Teks. (Terj. Agustinus Hartono). Yogyakarta: Jalasutra.

Danesi, Marcel. (2010). Pesan, Tanda, dan Makna. Terj. Evi Setyarini dan Lusi Lian Piantari. Yogyakarta: Jalasutra.

Kerrigan, Finola. (2010). Film Marketing. Burlington: Elsevier.

Kriyantono, Rachmat. (2010). Teknik Praktis Riset Komunikasi. Jakarta: Kencana Prenada Media Group.

Littlejohn, Stephen W. Karen A. Foss. (2009). Teori Komunikasi. (Terj. Muhammad Yusuf Hamdan). Jakarta: Salemba Humanika.

Sudibyo, Agus. (2014). 34 Prinsip Etis Jurnalisme Lingkungan. Jakarta: Gramedia.

\section{Article in a Scientific Journal}

Hadi, Ido P. (2008). Penelitian Khalayak Dalam Perspektif Reception Analysis. Jurnal Ilmiah SCRIPTURA, Vol. 2, No. 1, Januari 2008: 1 - 7.

\section{Electronic/Internet Source}

Sasono, Eric. (2019). Refleksi atas Sexy Killers: Penonton sebagai Publik. http://www.remotivi.or.id/amatan/520/Refleksi-atas-Sexy-Killers:-

Penonton-sebagai-Publik. October 10, 2019. 